\title{
HUBUNGAN KONSUMSI MINUMAN RINGAN DENGAN pH SALIVA PADA MAHASISWA PROGRAM STUDI KEDOKTERAN FAKULTAS KEDOKTERAN UNIVERSITAS MALIKUSSALEH TAHUN 2019
}

\author{
Nora Maulina $^{1}$, Harvina Sawitri ${ }^{1}$, Anna Millizia ${ }^{2}$ \\ ${ }^{1}$ Program Studi Kedokteran, Fakultas Kedokteran, Universitas Malikussaleh \\ ${ }^{2}$ Program Studi Profesi Dokter, Fakultas Kedokteran, Universitas Malikussaleh \\ Corresponding Author : nora.maulina@unimal.ac.id
}

\begin{abstract}
Abstrak
Derajat keasaman $(\mathrm{pH})$ saliva merupakan faktor penting yang berperan dalam rongga mulut, agar saliva dapat berfungsi dengan baik maka susunan serta sifat dari saliva harus tetap terjaga dalam keseimbangan yang optimal, khususnya derajat keasaman. Salah satu penyebab ketidakseimbangn saliva adalah pemilihan minuman ringan bersoda. Penurunan $\mathrm{pH}$ saliva dapat menyebabkan demineralisasi elemen-elemen gigi dengan cepat, sedangkam keneikan $\mathrm{pH}$ dapat membentuk kolonisasi bakteri yang menyimpan juga meningkatkan kalkulus. Konsumsi minuman ringan cenderung meningkat dari tahun ke tahun, namun tanpa disadari zat-zat yang terkandung di dalam minuman ringan dapat menyebabkan permasalahan pada gigi dan mulut di masa mendatang. Penelitian ini adalah penelitian observasional dengan menggunakan disain cross sectional, pada 57 mahasiswa Prodi Kedokteran FK Unimal yang dilakukan dengan teknik sampling purposive sampling. Hasil penelitian menunjukkan $28 \%$ responden tidak mengkonsumsi minuman ringan sama sekali dalam seminggu dan yang mengkonsumsi minuman sebanyak 5 kali dalam seminggu adalah 8,8\%. Sebanyak 45,6\% ph saliva bersifat asam. Uji chi square mengenai hubungan kosumsi minuman ringan dengan $\mathrm{pH}$ saliva didapatkan $\mathrm{p}$ value $=0,000(\mathrm{pv}<0,05)$, sehingga dapat diambil kesimpulan bahwa terdapat hubungan yang bermakna antara konsumsi minuman ringan dengan $\mathrm{pH}$ saliva.
\end{abstract}

Kata Kunci : minuman-ringan, pH-saliva, kesehatann gigi-dan-mulut

\section{Relationship between Soft Drink Consumption with Ph Saliva On Medicine Students Of Medicine Fakulty 2019}

\begin{abstract}
The degree of acidity $(\mathrm{pH})$ of saliva is an important factor that plays a role in the oral cavity, so that saliva can function properly, the composition and characteristics of saliva must be maintained in an optimal balance, especially the degree of acidity. One of the causes of saliva imbalance is the choice of soft soft drinks. Decreasing the $\mathrm{pH}$ of saliva can cause rapid demineralization of dental elements, whereas a sharpening of $\mathrm{pH}$ can colonize bacteria which store also increases calculus. Consumption of soft drinks tends to increase from year to year, but without realizing it, the substances contained in soft drinks can cause problems with teeth and mouth in the future. This study was an observational study using adesign cross sectional, on 57 students of the Medical Study Program FK Unimal, which was conducted by using purposive sampling technique. The results showed $28 \%$ of respondents did not consume soft drinks at all in a week and those who consumed drinks 5 times a week were $8.8 \%$. As much as $45.6 \%$ ph of saliva is acidic.test Chi square regarding the relationship between soft drink
\end{abstract}


consumption and salivary $\mathrm{pH}$ obtained $\mathrm{p}$ value $=0.000(\mathrm{pv}<0.05)$, so it can be concluded that there is a significant relationship between soft drink consumption and salivary $\mathrm{pH}$.

Keywords: soft drinks, $p H$-saliva, dental-care

\section{PENDAHULUAN}

Rongga mulut mempunyai berbagai macam fungsi, yaitu sebagai mastikasi, fonetik dan juga estetik. Hal ini Mengakibatkan rongga mulut merupakan tempat paling rawan dari tubuh karena merupakan pintu masuk berbagai agen berbahaya, seperti mikroorganisme, agen karsinogenik, selain itu juga rentan terhadap trauma fisik, kimiawi, dan mekanis (1). Dalam rongga mulut terdapat saliva yang merupakan suatu cairan yang sangat penting selain cairan celah gusi. Saliva membantu pencernaan dan proses penelanan, di samping itu juga untuk mempertahankan integritas gigi, lidah, dan membrana mukosa mulut. Di dalam mulut, saliva adalah unsur penting yang dapat melindungi gigi terhadap pengaruh dari luar, maupun dari dalam rongga mulut itu sendiri. Makanan dapat menyebabkan ludah bersifat asam maupun basa (2).

Derajat keasaman $(\mathrm{pH})$ saliva merupakan faktor penting yang berperan dalam rongga mulut, agar saliva dapat berfungsi dengan baik maka susunan serta sifat dari saliva harus tetap terjaga dalam keseimbangan yang optimal, khususnya derajat keasaman. Karena $\mathrm{Ph}$ sangat terkait dengan beberapa aktivitas pengunyahan yang terjadi di rongga mulut. Penurunan $\mathrm{pH}$ saliva dapat menyebabkan demineralisasi elemen-elemen gigi dengan cepat, sedangkan kenaikan $\mathrm{pH}$ dapat membentuk kolonisasi bakteri yang menyimpan juga meningkatnya pembentukan kalkulus (3). Saliva adalah cairan dalam rongga mulut yang tersusun dari 98\% - 99\% air, sementara sekitar 2\% tersusun dari komponen organik, anorganik, elektrolit, mukus, zat- zat antimikroba, dan berbagai enzim (4).

Penelitian yang dilakukan oleh Nurfitriani tahun 2011 di Universitas Indonesia menyebutkan bahwa terdapat sebesar 56\% mahasiswa responden masuk ke dalam kategori tinggi dalam konsumsi minuman ringan berpemanis ${ }^{10}$ Penelitian Suryanti tahun 2013 di Universitas Hasanuddin menyebutkan skor konsumsi Coca-cola pada mahasiswa adalah sebesar 0,107 atau sekali seminggu dan rata-rata asupan karbohidrat yang dihasilkan dari konsumsi soft drink yaitu 7,03 gram (5).

Faktanya baik minuman berkarbonasi maupun minuman rasa buah digemari oleh sebagian besar masyarakat dan minuman-minuman tersebut juga sangat mudah ditemukan di pasaran. Konsumsi minuman ringan cenderung meningkat dari tahun ke tahun, namun 
tanpa disadari zat-zat yang terkandung di dalam minuman ringan dapat menyebabkan permasalahan pada gigi dan mulut di masa mendatang (6).

Hasil Riset Kesehatan Dasar Nasional (Riskesdas) tahun 2007 menyebutkan bahwa $23,4 \%$ penduduk Indonesia mempunyai masalah kesehatan gigi dan mulut dan hanya 29,6\% penduduk diantaranya yang menerima perawatan dan pengobatan dari tenaga kesehatan gigi. Hal ini mengindikasikan bahwa masih terdapat masyarakat yang belum menyadari pentingnya pemeliharaan kesehatan gigi dan mulut. Penyakit gigi dan mulut yang ditemukan di masyarakat masih berkisar penyakit yang menyerang jaringan keras gigi (karies) dengan Indeks DMF-T nasional sebesar 4,85 (7).

\section{METODE PENELITIAN}

Penelitian ini adalah penelitian observasional dengan menggunakan disain cross sectional, yaitu studi epidemiologi yang mempelajari prevalensi, distribusi, maupun hubungan penyakit dan paparan dengan mengamati status paparan, penyakit atau outcome lain secara serentak pada individu- individu dari suatu populasi pada suatu saat.

\section{HASIL PENELITIAN}

1. Gambaran Kebiasaan Konsumsi Minuman Ringan pada Mahasiswa Program Studi Kedokteran Universitas Malikussaleh

Tabel Distribusi Frekuensi Minum Minuman Ringan pada Responden

\begin{tabular}{|c|c|c|}
\hline $\begin{array}{c}\text { Frekuensi konsumsi } \\
\text { minuman ringan dalam } \\
\text { seminggu }\end{array}$ & Jumlah & Persentase \\
\hline 0 & 16 & 28,1 \\
\hline 1 & 11 & 19,3 \\
\hline 2 & 10 & 17,5 \\
\hline 3 & 5 & 8,8 \\
\hline 4 & 10 & 17,5 \\
\hline 5 & 5 & 8,8 \\
\hline Total & 57 & 100 \\
\hline
\end{tabular}

Hasil wawancara dengan responden mengenai jumlah konsumsi minuma ringan dalam seminggu, dapat disimpulkan bahwa $28 \%$ responden tidak mengkonsumsi minuman ringan sama sekali dalam seminggu dan yang mengkonsumsi minuman sebanyak 5 kali dalam seminggu adalah $8,8 \%$. 


\section{Gambaran pH Saliva Mahasiswa Program Studi Kedokteran Universitas}

Malikussaleh

Tabel Distribusi Frekuensi pH Saliva pada Responden

\begin{tabular}{|l|c|c|}
\hline \multicolumn{1}{|c|}{ Ph Saliva } & Jumlah & Persentase \\
\hline Asam & 26 & 45,6 \\
\hline Normal & 31 & 54,4 \\
\hline Total & 57 & 100 \\
\hline
\end{tabular}

Dari tabel diatas, dapat diambil kesimpulan bahwa sebesar 45,6\% ph Saliva mahasiswa

Program Studi Kedokteran adalah asam dan 54,4\% normal.

\section{Hubungan Konsumsi Minuman Ringan dengan pH Saliva pada Mahasiswa Program}

Studi Kedokteran Universitas Malikussaleh

\begin{tabular}{|c|c|c|c|c|c|c|}
\hline \multirow{2}{*}{ Konsumsi Minuman Ringan } & \multicolumn{4}{|c|}{ pH Saliva } & \multirow{3}{*}{ Total } & \multirow{2}{*}{ p value } \\
\cline { 2 - 6 } & \multicolumn{3}{|c|}{ Asam } & \multicolumn{2}{|c|}{ Normal } & \\
\cline { 2 - 6 } & $\mathbf{N}$ & $\mathbf{\%}$ & $\mathbf{n}$ & $\mathbf{\%}$ & & \\
\hline 0 & 0 & 0 & 16 & 100 & 16 & \\
\hline 1 & 0 & 0 & 11 & 100 & 11 & \multirow{2}{*}{0,000} \\
\hline 2 & 8 & 80 & 2 & 20 & 10 & \\
\hline 3 & 5 & 100 & 0 & 0 & 5 & \\
\hline 4 & 8 & 80 & 2 & 20 & 10 & \\
\hline 5 & 5 & 100 & 0 & 0 & 5 & \\
\hline
\end{tabular}

Berdasarkan hasil tabel diatas, dapat diambil kesimpulan bahwa responden yang mengkonsumsi minuma ringan sebanyak 3 dan 5 kali, 100\% pH salivanya menjadi asam. Sedangkan responden yang mengkonsumsi minuman ringan sebanyak 0 dan $1 \mathrm{kali}, 100 \% \mathrm{pH}$ salivanya normal. Uji Chi square mengenai hubungan kosumsi minuman ringan dengan $\mathrm{pH}$ saliva didapatkan $\mathrm{p}$ value $=0,000(\mathrm{pv}<0,05)$, sehingga dapat diambil kesimpulan bahwa terdapat hubungan yang bermakna antara konsumsi minuma ringan dengan $\mathrm{pH}$ saliva.

\section{PEMBAHASAN}

\section{Minuman Ringan}

Salah satu temuan menarik adalah bahwa minuman ringan merupakan minuman yang paling digemari oleh sebagian besar kelompok remaja. Rata-rata para remaja mengkonsumsi dua kaleng/botol dalam kurun waktu satu minggu (8). Hal ini terjadi karena pada masa remaja cenderung terjadi perubahan-perubahan yang cepat dalam aspek kognitif dan emosi sehingga remaja cenderung selalu ingin mencoba trend baru. Remaja cenderung menjadikan konsumsi minuman ringan sebagai gaya hidup (9). Minuman ringan mengandung karbohidrat sederhana dalam konsentrasi yang tinggi, yaitu glukosa, fruktosa, sukrosa, dan kandungan 
gula sederhana lainnya. Kebanyakan, minuman ringan mengandung zat asam dan memiliki pH 3,0 atau lebih rendah sehingga dapat menyebabkan demineralisasi pada jaringan keras gigi (10). pH saliva akan kembali pada keadaan normal dalam waktu 30 detik setelah terpapar oleh minuman ringan. Minuman bersoda ini merupakan air yang disertai dengan karbon dioksida yang menjadikannya sebagai air karbonasi. Secara umum minuman ringan dapat berupa cola, air berasa, air bergas, teh manis, lemonade, squash, dan fruitpunch ${ }^{42}$.

\section{pH saliva}

Saliva adalah air dan biasanya berbusa yang diproduksi mulut manusia dan beberapa hewan. Saliva disekresikan oleh kelenjar saliva. Saliva manusia mengandung air paling banyak, tetapi juga mengandung elektrolit, mukus, komponen anti bakteri dan berbagai enzim sebagai bagian dari proses pencernaan makanan awal, enzim-enzim dalam saliva menghancurkan beberapa produk lemak sampai level molekuler. Saliva membantu pencernaan mekanis yang dilakukan oleh gigi, melindungi gigi dari bakteri yang dapat menyebabkan karies. Selain itu saliva berfungsi sebagai pelumas dan pelindung gigi, lidah, dan jaringan lunak dalam mulut, $\mathrm{pH}$ saliva merupakan derajat keasaman yang terkandung dalam saliva atau air ludah yang berkisar dari $0-14$ dengan perbandingan terbalik, dimana semakin rendah nilai $\mathrm{pH}$, maka semakin asam kandungan didalam saliva. Sebaliknya, meningkatnya nilai $\mathrm{pH}$ berarti bertambahnya basa dalam saliva. Semakin rendah $\mathrm{pH}$ saliva maka karies cenderung semakin tinggi (11)

\section{Minuman Ringan dan pH Saliva}

Minuman ringan merupakan faktor ektrinsik dari kejadian perubahan $\mathrm{pH}$ saliva mulut. Minuman ringan mengandung karbohidrat sederhana dalam konsentrasi yang tinggi seperti glukosa, fruktosa, sukrosa serta kandungan gula sederhana lainnya. Umumnya minuman ringan mengandung asam karbonat, asam fosfor, asam malat, asam sitrat, asam tartarat dengan $\mathrm{pH}$ yang $\operatorname{rendah}^{40}$ Penelitian ini sesuai dengan penelitian Aritonang (2014)(11,12)tentang hubungan frekuensi minum softdrink terhadap $\mathrm{pH}$ saliva dimana didapatkan hasil bahwa semakin banyak frekuensi minum soft-drink maka semakin rendah angka pH saliva. Penelitian oleh Rahmawati (2015)(12)menyimpulkan bahwa mengkonsumsi minuman ringan yang terlalu banyak dalam sehari akan mengakibatkan penurunan $\mathrm{pH}$ saliva dibawah normal. Frekuensi konsumsi minuman ringan yang berisiko akan menyebabkan perubahan $\mathrm{pH}$ saliva berada pada kondisi asam sehingga menyebabkan terjadinya 
demineralisasi pada gigi. Semakin sering seseorang dalam mengkonsumsi minuman ringan (softdrink) dalam satu hari maka akan meningkatkan pH saliva yang asam. Skinner (2015) menyatakan dalam penelitiannya bahwa konsumsi minuman manis pada remaja New South Wales didapatkan hasil mengkonsumsi dua gelas atau lebih minuman manis per hari menyebabkan peningkatan yang signifikan pada $\mathrm{pH}$ saliva Proses penetralisasi $\mathrm{pH}$ saliva membutuhkan waktu \pm 30 menit untuk kembali netral. Apabila dalam $<1$ jam seseorang mengkonsumsi minuman ringan (softdrink) secara terus menerus akan mempercepat risiko terjadinya karies gigi(11). Sebaiknya dalam mengkonsumsi minuman ringan (softdrink) dalam kurun waktu 1 jam hanya mengkonsumsi satu minuman ringan (softdrink) saja untuk mencegah proses demineralisasi yang terlalu lama akibat terpapar minuman ringan (softdrink) sehingga proses remineralisasi dapat terjadi dengan cepat. Cara konsumsi minuman ringan (softdrink) yang paling banyak dilakukan pada penelitian ini adalah cara mengkonsumsi yang berisiko atau menggunakan gelas dan langsung dari kemasan. Maka daripada itu, untuk mengurangi paparan atau kontak secara langsung dari mengkonsumsi minuman ringan (softdrink) lebih baik dengan menggunakan sedotan.

\section{KESIMPULAN}

1. Sebagian besar mahasiswa Program Studi Kedokteran tidak mengkonsumsi minuman ringan sama sekali dalam seminggu dan yang mengkonsumsi minuman sebanyak 5 kali dalam seminggu adalah $8,8 \%$.

2. Sebanyak $45,6 \%$ ph Saliva mahasiswa Program Studi Kedokteran bersifat asam dan $54,4 \%$ bersifat normal.

3. Terdapat hubungan yang bermakna antara konsumsi minuma ringan dengan $\mathrm{pH}$ saliva pada mahasiswa Program Studi Kedokteran

\section{REFERENSI}

1. Hidayani T.A, Handajani J. Efek merokok terhadap status $\mathrm{pH}$ dan volume saliva pada laki-laki usia dewasa dan usia lanjut. Dent J: Dentika;2010: 15(2);145-9

2. Chrismawaty E. Peran struktur mukosa rongga mulut dalam mekanisme blockade fisik terhadap iritan. MIKGI; 2006: V: 244-9.

3. Minasari. Peranan saliva dalam rongga mulut. Dent J: Majalah Kedokteran Gigi USU; 1999: 4(2): 33-9.

4. Manjunatha. Anatomy and Oral Physiology Including Occlusion and Forensic Odontology, 1st ed. New Delhi : Jaypee Brothers Medical Publishers Ltd; 2013: 226-227, 229, 231. 
5. Suci, A. Hubungan antara faktor individu dan lingkungan dengan konsumsi minuman ringan berpemanis pada siswa/i SMA Negeri 1 Bekasi Tahun 2012. Depok : Fakultas Kesehatan Masyarakat Universitas Indonesia; 2012 : 5

6. Suryanti R. Gambaran Jenis dan Jumlah Konsumsi Fast Food dan Soft Drink pada Mahasiswa Obesitas di Universitas Hasanuddin tahun 2013. Makassar : Fakultas Kesehatan Masyarakat Universitas Hasanuddin; 2013: 60,62.

7. Machfoedz, ircham., 2008. Menjaga kesehatan gigi dan mulut anak-anak dan ibu hamil. .Fitramaya.Yogyakarta

8. Mulyanti, R. 2015. Perbedaan Konsumsi Minuman Bersoda dan Isotonik Terhadap Peningkatan Plak Gigi Mahasiswa Fakultas Kedokteran Gigi Universitas

9. Muhammadiyah Surakarta Angkatan 2014. Naskah Publikasi. Surakarta : Fakultas Kedokteran Gigi Universitas Muhammadiyah Surakarta

10. Aritonang, I. 2014. Hubungan Frekuensi Minum Soft Drink Terhadap pH Saliva dan Angka DMF-T pada Siswa/I Kelas XI IPA MAN 2 Model Jalan Williem Iskandar No.7A Kec. Medan Tembung Tahun 2014. Jurnal Ilmiah PANNMED, 9 (2)

11. Andam. Survei tren dan perilaku remaja. 2008. http://www.google.com/survei tren dan perilaku.htm (15 Juli 2009)

12. Emilia Y, Djamil MD, Syamsiatun NH. Faktor-faktor yang mempengaruhi konsumsi softdrink dan masa tulang siswa SLTP Stella Duce 2 Yogyakarta. http://www.google.com.htm (15 Juli 2009) 